測色した。

歯冠色範囲における数学的補正方法は次のように行う と最も誤差が小さくなった．まず三基準色票として色相 $10 \mathrm{YR}$ 彩度 3 で明度が $6 ， 7.5 ， 9$ を選ぶ。これらの色 票は日本規格協会が XYZ 值を公表している，以下これ らの值を公表値之呼ぶ，基本式は（補正值） $=\mathrm{K} \cdot($ 測定 值 $)^{1 / 3}+\mathrm{A}$ とし，公表值と補正值ができるだけ近づくよ うに $\mathrm{K}$ と A を定める，KとA はXYZ 值それぞれにつ いて定める。ささらに Y 值についてはメトリックヒュー (H), メトリッククロマ (C) を算出した後二重補正を 行った．歯冠色範用の色票 44 色について補正値を求め たところ公表値との色差平均は 1.45 であった。

以上の補正方法に基づきVITA のシェードガイドの 測定值を算出した．測定部位は雬頸部から切端にかけて 7 ブロックに分け，それぞれのシェードの代表值は中央 部 3 ブロックの平均とした。

代表值は明度 6-8, 色相 $10 \mathrm{YR}-5.0 \mathrm{Y}$, 彩度 2-4 の範囲にあった，各系統の比較を行うと $\mathrm{ABD}$ 系統の差 異はその色相にあった。同一明度の B 系統と比較し A 系統は赤味が強く $\mathrm{D}$ 系統は緑がかる傾向にある，C系 統は色相，彩度が A 系統に近似するものの，明度は低 值を示した。

各ブロック間の色差値を求めたところ，歯頸部（ブ ロック 1）と切端（ブロック７）では 15 程度であった。 また中央部と考えられるブロック 3 とブロック 5 におい てお 4 程度の色差が存在した。この值が 2.5 以上だとほ ぼ全員が色の違いを感じるといわれ，各ブロック間の色 差が大きいことがわかる．これらの色差の成分はおむに 明度と彩度であった。

\section{5. 血液透析患者における緊急切開排膿術の全身麻酔経} 験

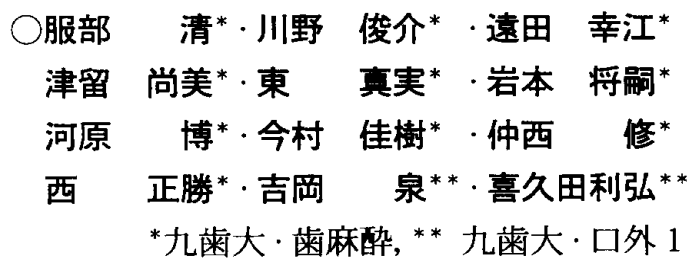

血液透析患者の数は年々増加傾向にあり，透析患者に 対する全身麻酔管理の症例も多く報告されている。この 場合の麻酔管理は，手術に先立ち透析担当医との連携の あとで綿密な手術計画を立て，術前に透析等により十分 に全身状態を是正してから行われている．また，このよ うな血液透析患者は，貣血，糖尿病，虚血性心疾患等の
全身合併症を有していることが多い，さらに易感染状態 にあり, 術後の呼吸器感染症等にも罹患しやすい，今 回，我々は 54 歳男性の血液透析患者における右側顔面 蜂窩織炎緊急切開排膿術の全身麻酔下にて施行する機会 を得たので報告する.

麻酔管理上の問題点として全身的には，慢性腎不全に よる電解質, 酸塩基平衡の異常や体液のバランスの異 常, 高窒素血症, C 型肝炎による肝機能障害, 腎性貧血 による酸素運搬能の低下，狭心症の既往よりそれに伴う 虚血発作の再発などがあげられる，また，局所的には， 炎症性開口障害により気道管理上の問題があげられる. さらに緊急手術であるため先に述べた全身的問題を術前 に十分対処できない点むあげられる.

我々は, これらの問題に対して, 術中, 術後の電解 質, 酸塩基平衡の適性保持, 挿管時および抜管後の気道 確保, 術中において肝機能障害をもたらす可能性のある 薬物の使用制限, 低酸素状態の防止, 出血, 術後の感染 予防等に留意して全身麻醉を施行した。

本症例においては腎不全に伴う水分出納, 電解質, 酸 塩基平衡の異常ならびに随伴合併症の増悪を引き起こす ことなく全身麻酔を終了した。

医療水準の向上に伴い今後このような血液透析患者の 増加が見込まれ，歯科口腔外科処置に際しての全身麻酔 患者管理の重要性を認識した。

\section{6. 山口県立中央病院歯科口腔外科入院患者 5 年間の臨 床統計的観察}

○上村 倰介·金川 昭啓 山口県立中央病院·歯口外

山口県立中央病院は山口県唯一の県立総合病院で総床 数 525 床を有する基幹病院である. 当科は定床 7 で 2 . 3 次救急をはじめ地域社会における顎・回腔領域医療の 一端を担っている．今回われわれは昭和 63 年 1 月から 平成 4 年 12 月まで 5 年間の当科入院患者 252 名につい て臨床統計的観察を行い，次のような結果を得た。

1. 外来新患者数 9,101 名のうち入院加療を要したの は 252 名で, 男性 149 名 (59.1\%), 女性 103 名 (40.9\%)であった.

2. 年間入院患者数は平均 $50.4 \%$. 年度別入院患者数 は経年的にわずかな増加傾向を認めた。

3. 年齢別入院患者数では 10 歳代が 42 名（16.7\%） と最も多く，50 歳代，40 歳代，20 歳代および 10 歳未満, 30 歳代の順に徐々に隇少していた. 60 歳 